\title{
Soil nutrient status and yield of rice under organic and inorganic inputs
}

\author{
Michael Troza, Anamae Sutacio, Al Polinar, Reuben James Cillo Rollon* \\ Department of Soil Science, Caraga State University, Butuan, Philippines.
}

\section{ARTICLE INFO \\ Article history: \\ Received on: June 22, 2021 \\ Accepted on: August 28, 2021 \\ Available online: November 10, 2021}

\section{Key words:}

Soil fertility, organic fertilizer, chemical fertilizer, rice productivity, rice profitability

\begin{abstract}
A field experiment was conducted to determine the effects of organic and inorganic fertilizer applications on soil fertility, productivity, and rice profitability. There were five treatment combinations with four replications laid out in Randomized complete block design (RCBD). The treatments were as follows: $T_{1}$ : control, $T_{2}$ : farmer's practice (FP), $T_{3}$ : recommended rate (RR), $T_{4}$ : organic fertilizer (OF), and $T_{5}: \mathrm{RR}_{50 \%}+\mathrm{OF}_{50 \%} \cdot \mathrm{RR}_{50 \%}+\mathrm{OF}_{50 \%}$ application significantly increased soil fertility after harvest. The $\mathrm{N}$ and $\mathrm{K}$ uptake of rice was also increased under FP and RR treatments. All yield components were increased with FP, RR, and $\mathrm{RR}_{50 \%}+\mathrm{OF}_{50 \%}$ treatments, with the consistently highest increase in the FP treatment. The highest grain yield obtained was in FP (6.68 $\mathrm{t}$ $\left.\mathrm{ha}^{-1}\right)$ followed by RR $\left(6.28 \mathrm{tha}^{-1}\right), \mathrm{RR}_{50 \%}+\mathrm{OF}_{50 \%}\left(6.12 \mathrm{tha}^{-1}\right)$, and OF $\left(5.25 \mathrm{tha}^{-1}\right)$, while the lowest yield was recorded in the control treatment $\left(4.67 \mathrm{t} \mathrm{ha}^{-1}\right)$. The net income was also increased by $43 \%$ in FP, 39\% in RR, and $34 \%$ in $\mathrm{RR}_{50 \%}+\mathrm{OF}_{50 \%}$ over the control. Maximum rice productivity and profitability were both obtained under FP. However, a similar yield and profit increase were also obtained in $\mathrm{RR}$ and $\mathrm{RR}_{50 \%}+\mathrm{OF}_{50 \%}$ treatments. The results highlighted the importance of combining organic and chemical fertilizers to reduce the cost of fertilizer inputs, increase soil fertility, improve rice yield, and maximize profitability in rice production.
\end{abstract}

\section{INTRODUCTION}

Rice is an important food crop in the Philippines. This crop is an excellent source of carbohydrates, nutrients, vitamins, and minerals [1]. In 2017, the population consumed around 11.7 million tons of rice. Philippine's rice production has continued to decline for three successive years. The volume of rice production (18.81 Mt) contracted by $1.3 \%$ in 2019 compared to last year's output [2]. Moreover, with the growing population, rice's global demand continues to rise from $439 \mathrm{Mt}$ in 2010 to $496 \mathrm{Mt}$ in 2020 and $555 \mathrm{Mt}$ in 2035 [3]. Hence, rice production needs to be increased significantly.

The country's rice production faces several challenges, contributing to its lower production. These include climate change, reduced land area, high cost of inputs, inadequate irrigation facilities, biotic and abiotic stresses (e.g., pest, drought,

*Corresponding Author

Reuben James Cillo Rollon, Department of Soil Science, Caraga State University, Butuan, Philippines.E-mail: rollonreubenjames@gmail.com and salinity), declining soil fertility, and inefficient use of fertilizers. Moreover, acidic and saline soils that are not fertile or productive have also accounted for 1.2 million ha, about half of the country's total rice production area [4]. Soil fertility decline is commonly observed in areas where low-input agriculture is practiced. Although farmers recognized the importance of applying fertilizer to attain high crop production, due to high costs, they are forced to grow crops yearly without replacing the nutrients removed by crops. Therefore, nutrient replenishment through fertilizer application is necessary.

Higher rice productivity is possible through balanced fertilizer application using inorganic and organic fertilizers (OF). Also, applying the proper amount of fertilizer and timing of application is necessary for efficient fertilizer use. Integrated use of chemical fertilizer with organic manure is a promising nutrient management approach for achieving higher crop productivity and maintaining soil fertility. OFs are naturally occurring fertilizers derived from plant and animal matter. The benefits of OF application include an increase in soil organic matter, cation exchange capacity, higher nutrient availability, soil $\mathrm{pH}$ regulation, increased water holding capacity, reduced 
soil compaction, and microbial activity stimulation [5-9]. Moreover, OF continuously delivers nutrients on a broader spectrum over time, thus providing a steady supply of nutrients to plants. On the other hand, chemical fertilizers are synthetic materials consisting of chemical combinations of two or more elements. Nutrient content in chemical fertilizers is high, readily soluble, and immediately available to plants [10]. Therefore, the effect on plants is usually direct and fast.

OF application solely or combined with chemical fertilizer has increased crop yield and improved soil fertility. In the study conducted by Ahmed et al. [11], the combined application of farmyard manure along with chemical fertilizer resulted in the build-up of organic carbon $(\mathrm{C})$, increased available nitrogen $(\mathrm{N})$, phosphorus $(\mathrm{P})$, and potassium $(\mathrm{K})$ in soil, higher nutrient uptake $(\mathrm{N}$ and $\mathrm{P}$ ), grain and straw yield of rice. Likewise, the combined application of organic (composted rice straw) and inorganic fertilizers remarkably increased nutrient ( $\mathrm{N}$ and $\mathrm{P}$ ) availability, grain yield, straw yield, and yield components of rice [12]. The increase in yield was attributed to a rise in soil fertility and enhanced crop nutrition. Despite the yield increase reported with integrating organic and chemical fertilizer, yield variation in some studies has been observed. The yield differences may be attributed to the type of fertilizer combination, the nutrient composition of $\mathrm{OF}$, application rate, and soil properties. In the study conducted by Iqbal et al. [13], a superior yield of rice and higher panicle number, dry matter accumulation, $\mathrm{N}$ uptake, and improved soil properties were observed using poultry manure and chemical fertilizer over chemical fertilizer alone. Likewise, half chemical fertilizer and half poultry manure applications resulted in taller plant growth, higher tiller numbers, and maximum dry matter, yield, and yield components over rice than lone chemical fertilizer [14]. In contrast, Baghdadi et al. [15] reported no difference in yields, plant growth characteristics, and nutritive quality between the full recommended dose of chemical fertilizer and combined organic and chemical fertilizer. With these results, further evaluation is needed to assess the effectiveness of organic and inorganic fertilizer application alone or in combination on soil fertility, plant nutrition, productivity, and profitability of rice. The main objective of the study was to determine the impact of organic and inorganic fertilizer application on selected soil chemical properties, nutrient concentration and uptake, yield, and yield components of rice. Moreover, this study aimed to determine the most profitable rice production treatment.

\section{MATERIALS AND METHODS}

\subsection{Experimental Site}

The study was conducted at the College of Agriculture and AgriIndustries Rice Experimental Site, Caraga State University, Butuan City, Philippines, from May 2018 to September 2018. The test site was flat with an elevation of $20 \mathrm{~m}$ above sea level and was fully irrigated. The soil was classified as Typic Epiaquepts, had a loamy texture, and was poorly drained [16]. Butuan City has a type IV climate, and rainfall is evenly divided all year round. Before starting the experiment, a bulk soil sample from $0-20 \mathrm{~cm}$ depth was collected from the site for initial chemical analysis. The sample was air-dried, sieved $(2 \mathrm{~mm})$, pulverized, and analyzed for $\mathrm{pH}$, total organic carbon $(\mathrm{OC})$, total $\mathrm{N}$, extractable $\mathrm{P}$, and exchangeable $\mathrm{K}$, calcium $(\mathrm{Ca})$, magnesium $(\mathrm{Mg})$, and sodium $\mathrm{Na}$ at the Regional Soils Laboratory in Butuan City.

\subsection{Experimental Design and Treatment Details}

The experiment was laid out in RCBD with five treatment combinations and four replications. The treatments are as follows: $\mathrm{T}_{1}$ : control, $\mathrm{T}_{2}: \mathrm{FP}, \mathrm{T}_{3}: \mathrm{RR}, \mathrm{T}_{4}: \mathrm{OF}$, and $\mathrm{T}_{5}: \mathrm{RR}_{50 \%}+\mathrm{OF}_{50 \%}$.

The FP treatment (159-21-51 kg N-P $\mathrm{O}_{5}-\mathrm{K}_{2} \mathrm{O}$ ha ${ }^{-1}$ ) was based on the survey conducted on select farmers in the area. The top five farmers that obtained high yields were selected, and the average fertilizer application rate was calculated, which was the basis for this treatment. Six bags of urea (46-0-0) were applied at 21 days after transplanting (DAT), followed by three bags of complete (14-14-14) at 45 DAT and one bag of muriate of potash (0-0-60) at 60 DAT.

The RR treatment (70-7-37 kg N-P $\mathrm{O}_{5}-\mathrm{K}_{2} \mathrm{O}^{-1}$ ) was derived from the chemical analysis of the soil conducted in the area. Fertilizer materials were split-applied into three. The first application was satisfied using one bag of complete plus 1.5 bags of ammonium sulfate (21-0-0) at 21 DAT, the second application using 2.25 bags of ammonium sulfate at $32 \mathrm{DAT}$, and lastly using 2.25 bags of ammonium sulfate plus one bag of muriate of potash which was applied at 45 DAT.

The OF treatment was a combination of $50 \%$ chicken manure $(\mathrm{CM}), 25 \%$ sawdust $(\mathrm{SD})$, and $25 \%$ carbonized rice hull $(\mathrm{CRH})$ $\mathrm{v} / \mathrm{v}$ applied at $10 t \mathrm{ha}^{-1}$. The fertilizer was broadcasted on the surface during the last harrowing operation and was incorporated manually after application. One month thereafter, rice seedlings were then transplanted.

For the combined treatment $\left(\mathrm{RR}_{50 \%}+\mathrm{OF}_{50 \%}\right)$, half of the recommended dose of fertilizer (35-3.5-18.5 $\mathrm{kg} \mathrm{N}-\mathrm{P}_{2} \mathrm{O}_{5}-\mathrm{K}_{2} \mathrm{O} \mathrm{ha}^{-1}$ ) and half OF $\left(5 t \mathrm{ha}^{-1}\right)$ were applied. The organic amendment was broadcasted in the designated plot and manually incorporated in the soil by hand 1 month before planting. Chemical fertilizer, on the other hand, was split-applied into three. A control treatment with no fertilizer applied was added as part of the treatments.

\subsection{Collection and Analysis of $\mathrm{CM}, \mathrm{CRH}$, and SD}

$\mathrm{CM}$ was collected from a poultry farm at Brgy, Tiniwisan, Butuan City, while SD was collected at Brgy, Ampayon, Butuan City. CM was air-dried for 5 days, pulverized, and sieved using $4 \mathrm{~mm}$ mesh. $\mathrm{CRH}$, on the other hand, was purchased from a rice miller at Brgy, Sumilihon, Butuan City. Both CRH and SD were sun-dried and sieved $(4 \mathrm{~mm})$ to facilitate proper mixing. The organic materials were mixed at a ratio of 2:1:1 $(50 \% \mathrm{CM}, 25 \% \mathrm{SD}$, and $25 \% \mathrm{CRH}$ $\mathrm{v} / \mathrm{v})$. A $200 \mathrm{~g}$ sample from each material was analyzed for $\mathrm{pH}, \mathrm{OC}$, $\mathrm{N}, \mathrm{P}$, and $\mathrm{K}$ at the Regional Soils Laboratory.

\subsection{Land Preparation}

The experimental area was cultivated using a floating tiller machine with three passings (first, second, and third). The first passing was conducted after the rice field was irrigated to soften the soil. The cultivated area was submerged for 5-7 days to decompose plant residues of the previous crop. The second 
passing was done 1 week after submergence and then followed by the third passing a week after the second passing. Finally, the cultivated area was leveled using an animal-drawn leveling board a day before transplanting. Four blocks with a $1.5 \mathrm{~m}$ distance between each other were constructed. Each block was divided into five experimental plots with $5 \times 4 \mathrm{~m}$ dimensions. A plot had an alley of $1 \mathrm{~m}$ with each other. Moreover, levees (30 $\mathrm{cm}$ high) were also constructed in each plot to avoid the movement of water and fertilizer.

\subsection{Seedling Transplanting and Management}

A 24-day-old seedling (Rc 122 rice variety) was transplanted in each experimental plot. The planting distance was $20 \times 20$ $\mathrm{cm}$. A total of 1,500 seedlings were planted per plot (500 hills plot $^{-1}$ with three seedlings hill ${ }^{-1}$ ). After transplanting, the water from the plots was drained to facilitate root development and reirrigated seven DAT. Removal of weeds and prevention of pest infestation were done regularly. Also, periodical checking of water was done to maintain a 5-inch depth water level of the growing plants.

\subsection{Harvesting, Soil, and Plant Tissue Analysis}

Rice was harvested at 122 DAT after reaching its maturity. Ten representative sample hills plot $^{-1}$ were separately harvested for data collection. The remaining hills were harvested using a combined harvester for the grain yield and straw yield data collection. Soil samples in each plot were also collected 7 days after the harvest for chemical analysis. In each plot, soils from the plow layer $(0-20 \mathrm{~cm})$ were sampled using a nongalvanized spade. Five subsamples were collected in each plot and composited. About $500 \mathrm{~g}$ of air-dried, pulverized, and sieved $(2 \mathrm{~mm}$ ) soil samples in each treatment plot was submitted to the laboratory for $\mathrm{pH}$, total $\mathrm{OC}$, total $\mathrm{N}$, available $\mathrm{P}$, and $\mathrm{K}$ analysis. Plant samples (shoot) were also taken plot $^{-1}$ for N, P, and $\mathrm{K}$ analysis. The shoots were cleaned, washed with distilled water, air-dried, cut, packed in a paper bag, and submitted to the Regional Soils Laboratory for tissue analysis.

\subsection{Data Analyses}

Analysis of variance using STAR version 2.0.1 2014 was performed to test the means for all the parameters gathered. Tukey's honest significant difference test was performed in comparing fertilizer treatments. Simultaneously, Pearson's correlation analyses were carried out to analyze the relationship between the selected variables.

\section{RESULTS AND DISCUSSION}

\subsection{Initial Chemical Properties of Soil}

Table 1 presents the initial chemical properties of the soil before the start of the experiment. Soil chemical analyses revealed that it was slightly acidic with moderately low OC, very low $\mathrm{N}$, but high $\mathrm{P}$ content. On the other hand, the basic cation concentrations in the soil ranged from low to high. The $\mathrm{K}$ and $\mathrm{Ca}$ contents were low, there was a high amount of $\mathrm{Mg}$, and it had an optimal Na concentration.
Table 1: Initial chemical characteristics of soil.

\begin{tabular}{cc} 
Property & Soil \\
$\mathrm{pH}$ & 6.19 \\
Total OC (\%) & 1.91 \\
Total N (\%) & 0.002 \\
Extractable P (ppm) & 27.00 \\
Exchangeable $\mathrm{K}(\mathrm{ppm})$ & 107.00 \\
Exchangeable Ca (ppm) & 502.00 \\
Exchangeable $\mathrm{Mg}(\mathrm{ppm})$ & 658.73 \\
Exchangeable $\mathrm{Na}(\mathrm{ppm})$ & 74.18 \\
\hline
\end{tabular}

OC: organic carbon.

\subsection{Chemical Composition of CM, CRH, and SD}

The chemical characteristics of CM, CRH, and SD are presented in Table 2. The $\mathrm{pH}$ ranged from slightly alkaline $(\mathrm{pH} 7.58)$ to very strongly alkaline $(\mathrm{pH} 10.46)$. The $\mathrm{pH}$ values of organic amendments were in the order of $\mathrm{CRH}>\mathrm{CM}>\mathrm{SD}$. The total $\mathrm{OC}$ of the three organic amendments ranged from $1.51 \%$ to $56.62 \%$. SD had the highest OC content, followed by CM and CRH. Among OFs, CM was far more superior in nutrient compositions ( $\mathrm{N}, \mathrm{P}, \mathrm{K}$, $\mathrm{Mg}$, and $\mathrm{Na}$ ) than $\mathrm{CRH}$ and $\mathrm{SD}$. The nutrient composition was in the order $\mathrm{CM}>\mathrm{CRH}>\mathrm{SD}$.

\subsection{Soil Chemical Properties after Harvest}

After harvest, soil chemical properties were significantly affected by fertilizer application, except total $\mathrm{N}$ (Table 3). The highest increase in soil $\mathrm{pH}$, total OC, extractable $\mathrm{P}$, and exchangeable $\mathrm{K}$ has consistently been observed in the OFtreated plots. The increase in soil total $\mathrm{OC}$, available $\mathrm{P}$, and $\mathrm{K}$ in the OF treatment was $43 \%, 229 \%$, and $219 \%$, respectively, over the control plots. Likewise, soil $\mathrm{pH}$ in the OF-treated plot increased by 0.33 units relative to the control. Furthermore, plots amended with $\mathrm{RR}_{50 \%}+\mathrm{OF}_{50 \%}$ had significantly higher $\mathrm{pH}$, $\mathrm{OC}, \mathrm{P}$, and $\mathrm{K}$ than in the FP and RR treatments. Correlation analysis showed that soil OC was positively and very strongly associated with total $\mathrm{N}(r=0.93 ; p=<0.01)$, extractable $\mathrm{P}(r=0.94 ; p=<0.01)$, and exchangeable $\mathrm{K}(r=0.90 ; p=<0.01)$ (Table 4). This indicates that soil nutrient level increases with increasing $\mathrm{OC}$ content.

Table 2: Chemical characteristics of CM, carbonized rice hull, and sawdust used in the study.

\begin{tabular}{cccc} 
Property & CM & CRH & SD \\
pH & 10.24 & 10.46 & 7.58 \\
Total OC (\%) & 19.62 & 1.51 & 56.62 \\
Total N (\%) & 2.77 & 0.06 & 0.31 \\
Total P (\%) & 3.20 & 0.74 & 0.09 \\
Total K (\%) & 5.18 & 1.07 & 0.62 \\
Total Ca (\%) & 0.18 & 0.34 & 0.34 \\
Total Mg (\%) & 13.90 & 2.47 & 0.10 \\
Total Na (\%) & 1.52 & 0.43 & 0.06 \\
\hline
\end{tabular}

OC: organic carbon, CM: chicken manure, $\mathrm{CRH}$ : carbonized rice hull, and SD: sawdust 
Table 3: Means for the residual soil chemical properties of lowland rice as affected by organic and inorganic fertilizer application.

\begin{tabular}{cccccc} 
Treatments & $\mathbf{p H}$ & Total OC (\%) & Total N (\%) & Extractable P $(\mathbf{p p m})$ & Exchangeable K $(\mathbf{p p m})$ \\
$T_{1}$ : control & $6.45^{\mathrm{b}}$ & $2.10^{\mathrm{b}}$ & 0.38 & $26.25^{\mathrm{b}}$ & $81.00^{\mathrm{b}}$ \\
$T_{2}: \mathrm{FP}$ & $6.66^{\mathrm{a}}$ & $2.08^{\mathrm{b}}$ & 0.34 & $21.25^{\mathrm{b}}$ & $83.75^{\mathrm{b}}$ \\
$T_{3}: \mathrm{RR}$ & $6.41^{\mathrm{b}}$ & $2.20^{\mathrm{b}}$ & 0.36 & $22.00^{\mathrm{b}}$ & $78.00^{\mathrm{b}}$ \\
$T_{4}: \mathrm{OF}$ & $6.78^{\mathrm{a}}$ & $3.00^{\mathrm{a}}$ & 0.46 & $86.25^{\mathrm{a}}$ & $258.25^{\mathrm{a}}$ \\
$T_{5}: \mathrm{RR}_{50 \%}+\mathrm{OF}_{50 \%}$ & $6.67^{\mathrm{a}}$ & $2.62^{\mathrm{ab}}$ & 0.41 & $63.00^{\mathrm{ab}}$ & $150.25^{\mathrm{ab}}$ \\
\hline
\end{tabular}

Means in a column followed by common letters are not significantly different at the $5 \%$ level of significance. FP: farmer's practice, RR: recommended rate, OF: organic fertilizer, $\mathrm{RR}_{50 \%}+\mathrm{OF}_{50 \%}$ : half RR and half OF, and OC: organic carbon.

Our results showed that OF application improved soil fertility by raising the nutrient levels in the soil and providing favorable $\mathrm{pH}$ for plant growth. Mineralization of organically bound nutrients from manure provides a continuous supply of nutrients to the plants. Moreover, nutrients bound in organic materials are not easily leached from the soil, thus leaving a large amount of residual nutrients in the soil. An increase in soil organic matter with manure application may have increased soil cation exchange capacity, which increases soil nutrient retention. Lastly, with the increase in soil $\mathrm{pH}$, the bioavailability of plant nutrients also increases. These results agree with Mahmood et al. [17], who reported an increase in $\mathrm{OC}$, available $\mathrm{P}$, and $\mathrm{K}$ with $\mathrm{OF}$ alone or in combination with inorganic fertilizer. Likewise, Bokhtiar and Sakurai [18] reported higher soil OC, available P, and K with organic manure application and inorganic fertilizer.

\subsection{Tissue N, $P$, and $K$ Concentrations of Rice as Affected by Fertilizer Application}

Table 5 showed that $\mathrm{N}$ and $\mathrm{P}$ concentrations in rice were not significantly influenced by fertilizer application. The analysis revealed that tissue $\mathrm{N}$ and $\mathrm{P}$ concentrations in the control treatment were statistically at par with organic and inorganic fertilizer treatments, applied solely or combined. Tissue $\mathrm{N}$ concentrations ranged from $0.86 \%$ to $0.99 \%$, while $\mathrm{P}$ concentrations ranged from $0.07 \%$ to $0.78 \%$.

Tissue $\mathrm{K}$ concentration, on the other hand, varied significantly with fertilizer application (Table 5). The highest plant tissue $\mathrm{K}$ was recorded in the $\mathrm{RR}_{50 \%}+\mathrm{OF}_{50 \%}$ treatment, followed by sole $\mathrm{OF}$ and the control treatments. In contrast, plant tissue $\mathrm{K}$ in the

Table 4: Pearson correlation matrix for the selected parameters.

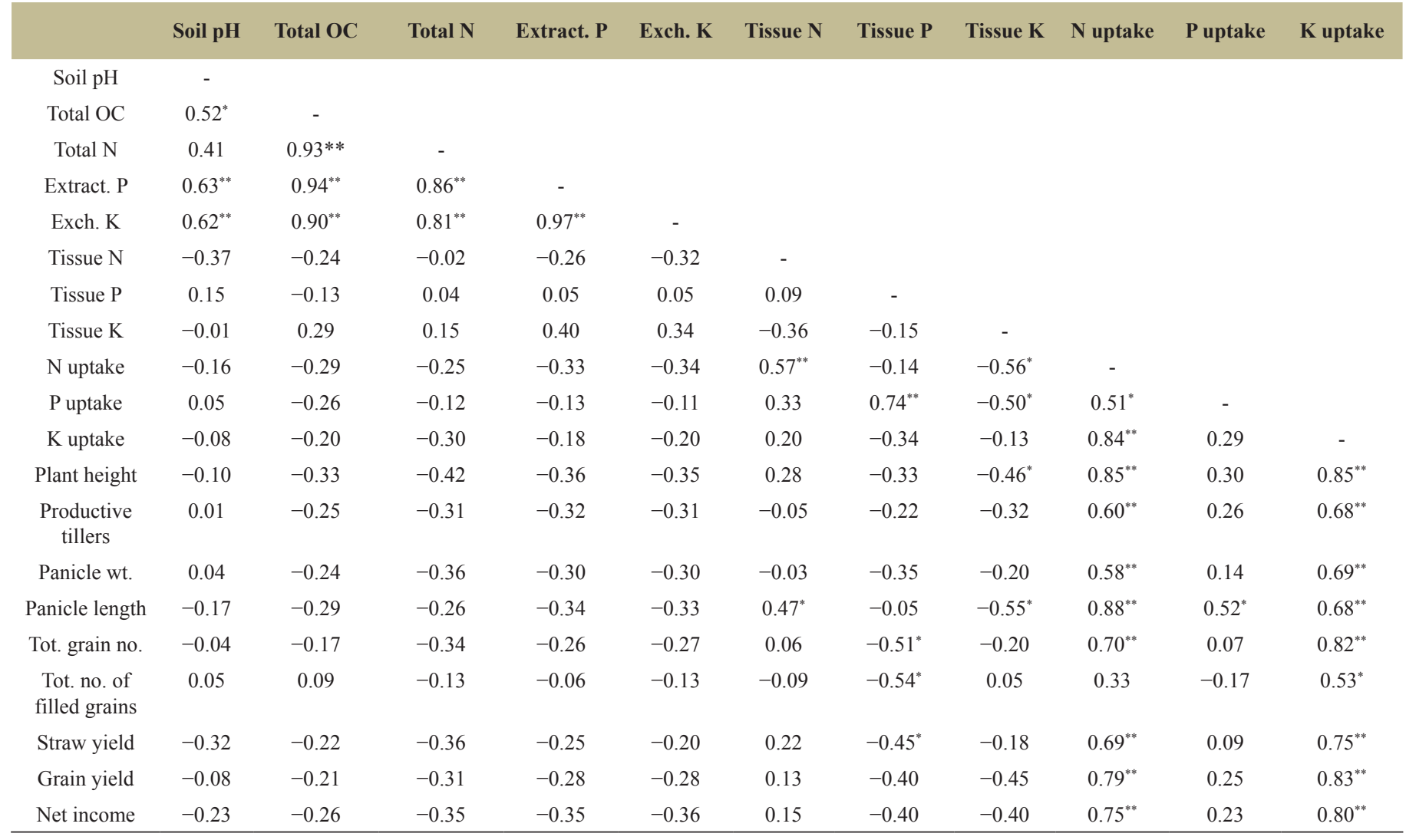

"Significant at $p<0.05$, "*significant $p<0.01$, and OC: organic carbon. 
Table 5: Means for the tissue N, P, and K content of rice as affected by organic and inorganic fertilizer application.

\begin{tabular}{cccc} 
Treatments & Tissue $\mathbf{N}(\%)$ & Tissue P $(\%)$ & Tissue K (\%) \\
$T_{1}$ : control & 0.98 & 0.11 & $2.61^{\mathrm{ab}}$ \\
$T_{2}: \mathrm{FP}$ & 0.99 & 0.07 & $2.21^{\mathrm{c}}$ \\
$T_{3}: \mathrm{RR}$ & 0.93 & 0.08 & $2.37^{\mathrm{bc}}$ \\
$T_{4}:$ OF & 0.86 & 0.78 & $2.64^{\mathrm{ab}}$ \\
$T_{5}: \mathrm{RR}_{50 \%}+\mathrm{OF}_{50 \%}$ & 0.90 & 0.07 & $2.74^{\mathrm{a}}$ \\
\hline
\end{tabular}

Means in a column followed by common letters are not significantly different at the $5 \%$ level of significance. FP: farmer's practice, RR: recommended rate, OF: organic fertilizer, and $\mathrm{RR}_{50 \%}+\mathrm{OF}_{50 \%}$ : half $\mathrm{RR}$ and half $\mathrm{OF}$.

FP plots was significantly reduced by $15 \%$ relative to the control. Also, tissue $\mathrm{K}$ concentrations in the RR treatment contracted by $9 \%$. This observed nutrient content reduction in the FP and RR treatments might have been attributed to the dilution effects because of the plants' higher biomass production. Generally, the $\mathrm{N}$ and $\mathrm{P}$ contents of rice recorded in the study were below the sufficiency range concentration, which could have been attributed to the remobilization of nutrients from the leaves to the grains during grain productions [19]. Meanwhile, K concentration, which ranged from $2.21 \%$ to $2.74 \%$, was sufficient for rice.

\subsection{Nutrient Uptake of Rice as Affected by Fertilizer Application}

Nutrient uptake measures the total amount of nutrients absorbed by plants per biomass produced. Generally, heavier plants will accumulate more nutrients in their tissues. In the study, the $\mathrm{N}$ uptake of rice ranged from $30.47 \mathrm{~kg} \mathrm{ha}^{-1}$ to $65.11 \mathrm{~kg} \mathrm{ha}^{-1}$ (Table 6). The highest $\mathrm{N}$ uptake was recorded in the FP treatment with a $110 \%$ increase over the untreated control. This was followed by $\mathrm{RR}$ and $\mathrm{RR}_{50 \%}+\mathrm{OF}_{50 \%}$ treatments with $49 \%$ and $32 \%$ increase, respectively, over the control. The highest $\mathrm{N}$ uptake recorded in the FP treatment was due to high application rates of $\mathrm{N}(159 \mathrm{~kg}$ $\mathrm{N}$ ha ${ }^{-1}$ ). The lowest $\mathrm{N}$ accumulation was observed in the sole $\mathrm{OF}$ and control treatment. Moreover, correlation analysis showed a positive and moderate linear relationship between $\mathrm{N}$ uptake and tissue $\mathrm{N}$ concentration $(r=0.57 ; p=<0.01)$ and $\mathrm{P}$ uptake $(r=0.51$; $p=<0.05)$ and a very strongly linear relationship with $\mathrm{K}$ uptake $(r=0.84 ; p=<0.01)$ (Table 4). Correlation analysis suggested a positive interaction between $\mathrm{N}, \mathrm{P}$, and $\mathrm{K}$.
Table 6: Means for the tissue N, P, and K uptake of rice as affected by organic and inorganic fertilizer application.

\begin{tabular}{cccc} 
Treatments & $\begin{array}{c}\text { N uptake } \\
\left.(\mathbf{k g ~ h a})^{-1}\right)\end{array}$ & $\begin{array}{c}\text { P uptake } \\
\left(\mathbf{k g ~ h a}^{-1}\right)\end{array}$ & $\begin{array}{c}\text { K uptake } \\
\left(\mathbf{k g ~ h a}^{-1}\right)\end{array}$ \\
$T_{1}:$ control & $31.02^{\mathrm{c}}$ & 3.41 & $82.39^{\mathrm{d}}$ \\
$T_{2}: \mathrm{FP}$ & $65.11^{\mathrm{a}}$ & 4.79 & $143.94^{\mathrm{a}}$ \\
$T_{3}: \mathrm{RR}$ & $46.28^{\mathrm{b}}$ & 4.18 & $118.01^{\mathrm{bc}}$ \\
$T_{4}: \mathrm{OF}$ & $30.47^{\mathrm{c}}$ & 2.74 & $94.15^{\mathrm{cd}}$ \\
$T_{5}: \mathrm{RR}_{50 \%}+\mathrm{OF}_{50 \%}$ & $41.08^{\mathrm{bc}}$ & 3.28 & $124.70^{\mathrm{ab}}$ \\
\hline
\end{tabular}

Means in a column followed by common letters are not significantly different at the $5 \%$ level of significance. FP: farmer's practice, RR: recommended rate, OF: organic fertilizer, and $\mathrm{RR}_{50 \%}+\mathrm{OF}_{50 \%}$ : half $\mathrm{RR}$ and half $\mathrm{OF}$.

Also, fertilizer application significantly influenced $K$ uptake in rice. The uptake values ranged from $82.39 \mathrm{~kg} \mathrm{ha}^{-1}$ to 143.94 $\mathrm{kg} \mathrm{ha}^{-1}$. The largest increase was recorded in the FP treatment, with a $75 \%$ increase in $\mathrm{K}$ over the control. Combined fertilizer application $\left(\mathrm{RR}_{50 \%}+\mathrm{OF}_{50 \%}\right)$ and $\mathrm{RR}$ treatments followed this with a $51 \%$ and $43 \%$ increase, respectively. In contrast, control plants had the lowest K uptake, followed by sole OF treatment. Higher $\mathrm{K}$ uptake of plants in the FP treatment was attributed to higher application rates of $K\left(51 \mathrm{~kg} \mathrm{ha}^{-1}\right)$ over $\mathrm{RR}\left(37 \mathrm{~kg} \mathrm{ha}^{-1}\right)$ and higher nutrient bioavailability. Lastly, there was no apparent difference found in P uptake among fertilizer treatments.

\subsection{Agronomic Characteristics and Yield Components of Rice}

\subsubsection{Plant height}

Fertilizer application had a significant effect on plant height at harvest. The largest plant height $(107.14 \mathrm{~cm})$ recorded was in the FP, with a $22 \%$ increase in height over the control treatment $(87.74 \mathrm{~cm})$ (Table 7). This was followed by the RR $(99.97 \mathrm{~cm})$ and $\mathrm{RR}_{50 \%}+\mathrm{OF}_{50 \%}$ treatments $(96.68 \mathrm{~cm})$ with a $14 \%$ and $10 \%$ increase in plant height, respectively. Meanwhile, the control treatment $(87.74 \mathrm{~cm})$ and the sole OF $(89.73 \mathrm{~cm})$ had comparable heights and were the shortest among the treatments. Larger plant heights in the FP, RR, and $\mathrm{RR}_{50 \%}+\mathrm{OF}_{50 \%}$ treatments might be due to better plant nutrition. Correlation analysis showed that plant height was very strongly associated with $\mathrm{N}$ uptake $(r=0.85 ; p=$ $<0.01)$ and $\mathrm{K}$ uptake $(r=0.85 ; p=<0.01)$ (Table 4). Thus, plant height increases with the increase in $\mathrm{N}$ and $\mathrm{K}$ uptake. Fertilizer application increased $\mathrm{N}$ uptake of plants, which produced more

Table 7: Means for the growth and yield components of lowland rice as affected by organic and inorganic fertilizer application.

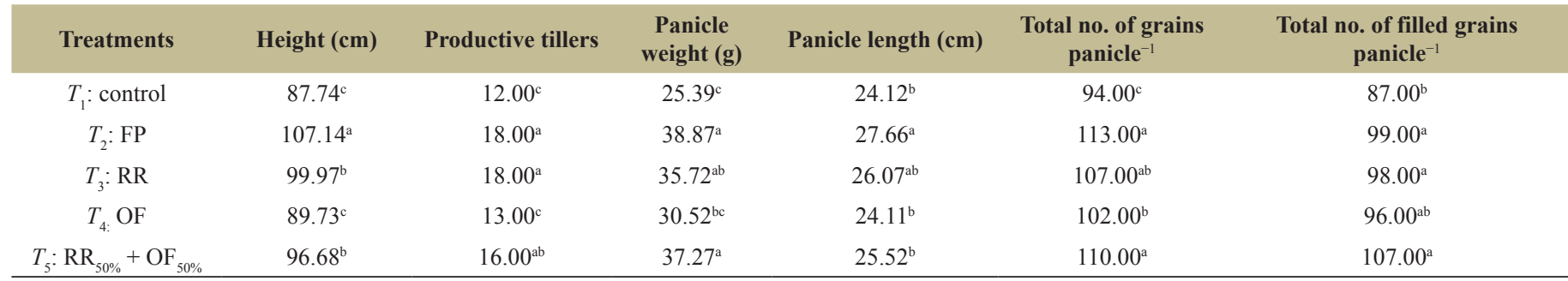

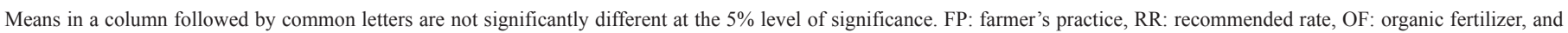
$\mathrm{RR}_{50 \%}+\mathrm{OF}_{50 \%}$ : half RR and half OF. 
leaf area resulting in higher photoassimilates production and dry matter accumulation [20]. On the other hand, K controls stomatal movement, regulates water balance, and increases nutrient uptake and carbohydrate movement in plant tissue. Thus, an increase in $\mathrm{K}$ is associated with vigorous plant growth. Djomo et al. [21] reported the same increase in plant height by applying the different doses of fertilizers using NPK. Rishikesh et al. [22] have also reported a significant increase in plant height with applied NPK fertilizer based on soil tests with or without farmyard manure. Likewise, the combined application of OF and NPK produced larger plant heights relative to control plants [23].

\subsubsection{Productive tillers}

Fertilizer application significantly increased the number of productive tillers plant ${ }^{-1}$. Productive tiller numbers ranged from 12 to 18 (Table 7). Maximum productive tillers were recorded in the FP (18 tillers) and RR (18 tillers) treatments which received inorganic fertilizer. Combined fertilizer application $\left(\mathrm{RR}_{50 \%}+\right.$ $\left.\mathrm{OF}_{50 \%}\right)$ also gave statistically similar tiller numbers (16 tillers) with the FP and RR treatments. Meanwhile, the OF-amended (13 tillers) and control (12 tillers) plants produced comparatively lower productive tillers than all other treatments. Higher tiller production in the FP and RR treatments might have been attributed to high application rates of $\mathrm{N}$ and $\mathrm{K}$. Correlation analysis showed that tiller production was strongly correlated with $\mathrm{N}$ uptake $(r=0.60 ; p=$ $<0.01)$ and $\mathrm{K}$ uptake $(r=0.68 ; p=<0.01)$ (Table 4). Thus, tiller production in rice increases with the increase in $\mathrm{N}$ and $\mathrm{K}$ uptake. $\mathrm{A}$ similar increase in the number of tillers due to increased $\mathrm{N}$ and $\mathrm{K}$ levels was reported by Yadanar et al. [24]. Nitrogen influences leaf development and leaf photosynthetic activity, while $\mathrm{K}$ improves carbohydrate metabolism in plants and increases plant vigor.

\subsubsection{Panicle weight and length}

Fertilizer application significantly increased the panicle weight plant $^{-1}$ and panicle length of rice. Heavier panicles were recorded in the $\mathrm{FP}, \mathrm{RR}_{50 \%}+\mathrm{OF}_{50 \%}$ and $\mathrm{RR}$ treatments, almost twice heavier than the panicles produced in the unamended (control) plants (Table 7). Meanwhile, the control and the organic amended (OF) plants had comparable panicle weights and weighed lighter than other fertilizer treatments.

Similarly, the FP and RR treatments produced longer and bigger panicles (Table 7), while panicles in control, $\mathrm{OF}$, and $\mathrm{RR}_{50 \%}+\mathrm{OF}_{50 \%}$ were smaller and statistically identical in length. Panicle weight and panicle length were both associated with $\mathrm{N}$ and $\mathrm{K}$ uptake. Panicle weights were moderately correlated with $\mathrm{N}$ uptake $(r=0.58 ; p=$ $<0.01)$ and strongly correlated with $\mathrm{K}$ uptake $(r=0.69 ; p=<0.01)$ (Table 4$)$, while panicle length were very strongly correlated with $\mathrm{N}$ uptake $(r=0.88 ; p=<0.01)$ and strongly correlated $(r=0.68$; $p=<0.01)$ with $\mathrm{K}$ uptake. Correlation suggested that panicle weight and length are increased when plants accumulate more $\mathrm{N}$ and $\mathrm{K}$ in their tissues. Heavier and longer panicles recorded in the FP were attributed to higher application rates of $\mathrm{N}$ and $\mathrm{K}$. A similar result was reported by Uddin et al. [25], who noted an increase in panicle length with increasing levels of $\mathrm{N}$ and $\mathrm{K}$ fertilizers. On the other hand, Mahmud et al. [26] reported a significant increase in panicle weight of rice with applied organic and chemical fertilizer.

\subsubsection{Total number of grains and number of filled grains panicle $e^{-1}$}

Fertilizer application significantly increased the total number of filled grains and total grains panicle ${ }^{-1}$ of rice (Table 7 ). Total grain numbers panicle ${ }^{-1}$ ranged from 94 to 113 , while the total number of filled grains panicle ${ }^{-1}$ ranged from 87 to 107. All fertilized plants produced more grains panicle ${ }^{-1}$ and filled grains panicle ${ }^{-1}$ over the control treatment. Among fertilizer-amended plots, the FP, RR, and $\mathrm{RR}_{50 \%}+\mathrm{OF}_{50 \%}$ treatments consistently produced more grains panicle $^{-1}$ and higher filled grain numbers over sole OF treatment. The highest grain numbers counted were in the FP, with more than $20 \%$ grains produced relative to the control. Simultaneously, the combination of inorganic and $\mathrm{OF}$ had 23\% higher filled grains panicle $^{-1}$ recorded over the control.

Moreover, total grain numbers were strongly associated with $\mathrm{N}$ uptake $(r=0.70 ; p=<0.01)$ and $\mathrm{K}$ uptake $(r=0.82 ; p=<0.01)$, while filled grain numbers were moderately correlated with $\mathrm{K}$ uptake $(r=0.53$; $p=<0.05$ ) (Table 4). The association was positive and significant. Thus, rice grain production and filled grain numbers panicle ${ }^{-1}$ increase with the increase in $\mathrm{N}$ and $\mathrm{K}$ uptake in plants. Interestingly, both yield parameters were negatively and moderately correlated with tissue $\mathrm{P}$ $(r=-0.51$ and $-0.54 ; p=<0.05)$. Hence, the production of grains and the number of filled grains panicle ${ }^{-1}$ are reduced as plant tissue $\mathrm{P}$ increases. $\mathrm{N}$ and $\mathrm{K}$ are the two most important nutrients during grain formation and grain filling. $\mathrm{N}$ increases photoassimilates production in plants, while $\mathrm{K}$ improves carbohydrate translocation and increases the fertility of pollen seeds, resulting in increased spikelet's panicle ${ }^{-1}$, percentage of filled grains, and grain weight of rice. The results of the study agree with the findings of Moe et al. [27]. They reported the highest percentage of filled grains and spikelet's number panicle ${ }^{-1}$ with combined chemical and OF.

\subsection{Grain Yield}

Fertilizer application significantly increased grain yield after harvest (Table 8). Grain yield ranged from $4.67 \mathrm{tha}^{-1}$ to $6.68 \mathrm{tha}$. The highest grain yield recorded was in the FP, with a $43 \%$ increase in yield over the control treatment. The $\mathrm{RR}, \mathrm{RR}_{50 \%}+\mathrm{OF}_{50 \%}$, and the sole OF treatments followed this with $26 \%, 24 \%$, and $11 \%$ yield increase, respectively, over the control. Grain yield production was strongly associated with nutrient uptake. Correlation analysis showed a positive and strong correlation between the yield and $\mathrm{N}$ $(r=0.79 ; p=<0.01)$ and $\mathrm{K}(r=0.83 ; p=<0.01)$ uptake (Table 4). In plants, $\mathrm{N}$ increases photosynthetic activity and photoassimilates production, while $\mathrm{K}$ improves carbohydrate metabolism and translocation. Thus, heavier grains and straw biomass in rice are often associated with higher plant $\mathrm{N}$ and $\mathrm{K}$ content [28,20]. Also, rice's higher grain yield response to $\mathrm{N}$ and $\mathrm{K}$ may be attributed to its high nutrient requirement. Our findings coincided with the observation of Sharma et al. [29], who reported a close association between crop yields and nutrient uptake. Moreover, positive and significant correlations between grain yield and plant height $(r=$ $0.87 ; p=<0.01)$, tiller number $(r=0.70 ; p=<0.01)$, panicle length $(r=0.74 ; p=<0.01)$, panicle weight $(r=0.73 ; p=<0.01)$, grain number panicle ${ }^{-1}(r=0.80 ; p=<0.01)$, and straw yield $(r=0.74$; $p=<0.01)$ were observed. Plants that developed more tillers, longer and heavier panicles, copious grains panicle ${ }^{-1}$, and heavier straws will produce higher grain yield. 
Table 8: Means for the dry straw yield, grain yield, and net income of rice as affected by organic and inorganic fertilizer application.

\begin{tabular}{cccc} 
Treatments & $\begin{array}{c}\text { Dry straw yield } \\
\left(\boldsymbol{t} \mathbf{h a}^{-1}\right)\end{array}$ & $\begin{array}{c}\text { Grain yield } \\
\left(\boldsymbol{t} \mathbf{h a}^{-1}\right)\end{array}$ & Net income (P) \\
$T_{1}:$ control & $3.16^{\mathrm{c}}$ & $4.67^{\mathrm{d}}$ & $55,494.00^{\mathrm{b}}$ \\
$T_{2}: \mathrm{FP}$ & $6.49^{\mathrm{a}}$ & $6.68^{\mathrm{a}}$ & $79,106.00^{\mathrm{a}}$ \\
$T_{3}: \mathrm{RR}$ & $4.98^{\mathrm{b}}$ & $6.28^{\mathrm{b}}$ & $77,225.00^{\mathrm{a}}$ \\
$T_{4}: \mathrm{OF}$ & $3.55^{\mathrm{c}}$ & $5.25^{\mathrm{c}}$ & $59,845.00^{\mathrm{b}}$ \\
$T_{5}: \mathrm{RR}_{50 \%}+\mathrm{OF}_{50 \%}$ & $4.55^{\mathrm{b}}$ & $6.12^{\mathrm{b}}$ & $74,201.50^{\mathrm{a}}$ \\
\hline
\end{tabular}

Means in a column followed by common letters are not significantly different at the $5 \%$ level of significance. FP: farmer's practice, RR: recommended rate, OF: organic fertilizer, and $\mathrm{RR}_{50 \%}+\mathrm{OF}_{50 \%}$ : half $\mathrm{RR}$ and half $\mathrm{OF}$

Furthermore, the combined application of organic and inorganic fertilizer increased grain yield production in rice. This finding agrees with the study of Moe et al. [27], who reported the highest yield in rice with applied half chemical fertilizer and half organic manure. Chemical fertilizers provide a readily soluble nutrient to plants, while OF's supply a more balanced mix of macro- and micronutrients. Similar findings were also reported by Rajput et al. [30], who reported a higher grain yield of rice with fertilizer application based on soil test value. Interestingly, the highest yield obtained in our study, which is $6.68 t \mathrm{ha}^{-1}$, was higher by $108 \%$ over the average yield (3.21 $\left.t \mathrm{ha}^{-1}\right)$ reported in the Caraga Region [31] and $42 \%$ higher than the average yield $\left(4.7 \mathrm{tha}^{-1}\right)$ reported using this variety. However, the present study only covers one cropping season. Hence, further study is needed to validate our result.

\subsection{Net Income}

The net income for one cropping season ranged from $P$ 55,494.00 to $P 79,106.00 \mathrm{ha}^{-1}$ (Table 8). The highest net income recorded was in the FP, with a $43 \%$ profit increase over the control treatment. Similarly, the RR and $\mathrm{RR}_{50 \%}+\mathrm{OF}_{50 \%}$ treatments had a comparable profit increase with $\mathrm{FP}$, which is equivalent to $39 \%$ and $34 \%$ increase in profit over the control. The order of increase in the net income is as follows: $\mathrm{FP}>\mathrm{RR}>\mathrm{RR}_{50 \%}+\mathrm{OF}_{50 \%}>\mathrm{OF}>$ control. The lowest net return of $\mathrm{P} 55,494.00$ was recorded in the control treatment. Interestingly, the highest net return obtained in the present study was higher by $\mathrm{P} 57,782.00$ from the average net return of $\mathrm{P} 21,324.00$ in rice production as reported by Philippine statistics authority (PSA) [2]. This is because farmer's practice produces the largest yield increase and net return among fertilizer treatments. However, the effects of $\mathrm{RR}$ and $\mathrm{RR}_{50 \%}+\mathrm{OF}_{50 \%}$ could not be discounted. Hence, in the study, farmers may alternatively opt to follow the fertilizer recommendation based on a soil test or a combination of organic and inorganic fertilizers to maximize profit.

\section{CONCLUSION}

Our study found significant differences in soil chemical properties, nutrient uptake, yield, yield components, and net income of rice. Sole OF application at $10 t \mathrm{ha}^{-1}$ significantly increased soil OC, available $\mathrm{P}$, and $\mathrm{K}$ after harvest. Meanwhile, FP, RR, and $\mathrm{RR}_{50 \%}$ $+\mathrm{OF}_{50 \%}$ treatments increased plant height, $\mathrm{N}$ and $\mathrm{K}$ uptake, and the yield components of rice. Generally, fertilizer application significantly increases grain yield in rice. However, a substantial yield increase was observed in the FP $\left(6.68 t \mathrm{ha}^{-1}\right)$ followed by $\mathrm{RR}\left(6.28 t \mathrm{ha}^{-1}\right)$ and $\mathrm{RR}_{50 \%}+\mathrm{OF}_{50 \%}\left(6.12 t \mathrm{ha}^{-1}\right)$ treatments. The most profitable treatment was observed in the FP (P79,106.00), which was also comparable with $\mathrm{RR}(\mathbf{P} 77,225.00)$ and $\mathrm{RR}_{50 \%}$ $+\mathrm{OF}_{50 \%}(\mathrm{P} 74,201.50)$. In contrast, the least productive $(4.67 t$ $\left.\mathrm{ha}^{-1}\right)$ and least profitable (P55,494.00) treatment was recorded in control. However, the study only examined the effects of fertilizer application in the first cropping season. Hence, further research is needed to confirm our results.

\section{CONFLICTS OF INTEREST}

The authors declare that they have no conflicts of interest.

\section{AUTHORS' CONTRIBUTIONS}

All authors took part in the conceptualization, design, and implementation of the experiment. The authors also performed data acquisition, data analysis, and interpretation. Further, all authors were involved in the manuscript writing and approved the submission of this paper.

\section{FUNDING}

There is no funding to report.

\section{ETHICAL APPROVALS}

This study does not involve experiments on animals or human subjects.

\section{PUBLISHER'S NOTE}

This journal remains neutral with regard to jurisdictional claims in published institutional affiliation.

\section{REFERENCES}

1. Ricepedia.org. Rice as food [Internet]. Ricepedia.org, 2021. Available via https://ricepedia.org/rice-as-food/nutritional-content (Accessed 18 February 2021)

2. PSA. Selected statistics on agriculture [Internet]. PSA, Quezon, Philippines, 2020. Available via https://psa.gov.ph/sites/default/ files/2_SSA2020 final_signed.pdf (Accessed 5 May 2020)

3. Fahad S, Adnan M, Noor M, Arif M, Alam M, Khan IA, et al. Major constraints for global rice production. In: Hasanuzzaman M, Fujita M, Nahar K, Biswas K (eds.). Advances in rice research for abiotic stress tolerance, Elsevier, Amsterdam, Netherlands, pp 1-22, 2019.

4. Sebastian LS, Alviola PA, Francisco SR. Bridging the rice yield gap in the Philippines. In: Papademetrio MK, Herath EM, Dent FJ (eds.). Bridging the rice yield gap in the Asia-Pacific region, FAO Regional Office for Asia and the Pacific, Bangkok, Thailand, pp 122-34, 2020.

5. Roy S, Kashem MA. Effects of organic manures in changes of some soil properties at different incubation periods. Open J Soil Sci 2014;4:81-6. doi:10.4236/ojss.2014.43011

6. Adekiya AO, Ejue WS, Olayanju A, Dunsin O, Aboyeji CM, Aremu $C$, et al. Different organic manure sources and NPK fertilizer on soil chemical properties, growth, yield and quality of okra. Sci Rep 2010;10(1):1-9. doi:10.1038/s41598-020-73291-x

7. Suwara I, Pawlak-Zareba K, Gozdowski D, Perzanowska A. Physical properties of soil after 54 years of long-term fertilization and crop rotation. Plant Soil Environ 2016;62(9):389-94.

8. Ewulo BS, Ojeniyi SO, Akanni DA. Effect of poultry manure on selected soil physical and chemical properties, growth, yield and nutrient status of tomato. Afr J Agric Res 2008;3(9):612-6. 
9. Aher SB, Lakaria BL, Kaleshananda S, Singh AB, Ramana S, Ramesh $\mathrm{K}$, et al. Effect of organic farming practices on soil and performance of soybean (Glycine max) under semi-arid tropical conditions in Central India. J Appl Nat Sci 2015;7(1):67-71.

10. Chen JH. The combined use of chemical and organic fertilizers and/ or biofertilizer for crop growth and soil fertility. Taipei Food Fert Tech Bull 2006;17:1-9.

11. Ahmed S, Basumatary A, Das KN, Medhi BK, Srivastava AK. Effect on integrated nutrient management on yield, nutrient uptake and soil fertility in autumn rice in an inceptisol of Assam. Ann Plant Soil Res 2014;16(3):192-7.

12. Elhabet $\mathrm{H}$. Effect of organic and inorganic fertilizers on rice and some nutrients availability under different water regimes. J Agric Sci Food Res 2018;9(4):1-6.

13. Iqbal A, He L, Ali I, Ullah S, Khan A, Khan A, et al. Manure combined with chemical fertilizer increases rice productivity by improving soil health, post-anthesis biomass yield, and nitrogen metabolism. PLoS One 2020;15(10):1-24. doi:10.1371/journal. pone.0238934

14. Moe K, Htwe AZ, Thu TTP, Kajihara Y, Yamakawa T. Effects on NPK status, growth, dry matter, and yield of rice (Oryza sativa) by organic fertilizers applied in field condition. Agric 2019;109(9):1-5. doi:10.3390/agriculture9050109

15. Baghdadi A, Halim RA, Ghasemzadeh A, Ramlan MF, Sakimin SZ. Impact of organic and inorganic fertilizers on the yield and quality of silage corn intercropped with soybean. PeerJ 2018;6(1):1-26. doi: $10.7717 /$ peerj. 5280

16. Carating RB, Galanta RG, Bacatio CD. The soils of the Philippines. Springer, Dordrecht, Netherlands, 2014.

17. Mahmood F, Khan I, Ashraf U, Shahzad T, Hussain S, Shahid M, et al. Effects of organic and inorganic manures on maize and their residual impact on soil physico-chemical properties. J Soil Sci Plant Nutr 2017;17:22-32.

18. Bokhtiar SM, Sakurai K. Effects of organic manure and chemical fertilizer on soil fertility and productivity of plant and ratoon crops of sugarcane. Arch Agron Soil Sci 2005;51(3):325-34. doi:o $\mathrm{rg} / 10.1080 / 03650340500098006$

19. Sahrawat KL. Plant nutrients: sufficiency and requirements. In: Lal R (ed.). Encyclopedia of soil science. Taylor and Francis, Philadelphia, PA, pp 1306-10, 2006.20.

20. Chaturvedi I. Effect of nitrogen fertilizers on growth, yield and quality of hybrid rice (Oryza sativa). J Cent Eur Agric 2005;6(4):611-8.

21. Djomo SH, Mbong GA, Malla DK, Suh C. Effect of different doses of NPK fertilizer on the growth and yield of rice in Ndop, Northwest of Cameroon. Afr J Agric Res 2017;12(15):1244-52.

22. Rishikesh T, Upadhyay AK, Rai HK, Sachidanand B, Pradip D, Rohit P. Influence of soil test based integrated fertilization on growth, productivity and quality parameters of rice in Central India. Int J Chem Stud 2018;6(1):1091-4. doi:10.13140/RG.2.2.31759.89761

23. Siavoshi M, Nasiri A, Laware SL. Effect of organic fertilizer on growth and yield components in rice (Oryza sativa L.). J Agric Sci 2011;3(3):217-24. doi:10.5539/jas.v3n3p217

24. Yadanar SM, Mar SS, Than AA, Ngwe K. Effect of nitrogen and potassium on yield and yield components of rice. In Proceedings of the Eleventh Agricultural Research Conference, 2018 October 24, Yezin Agricultural University, Naypyidaw, Myanmar, 2018.

25. Uddin S, Sarkar MAR, Rahman MM. Effect of nitrogen and potassium on yield of dry direct seeded rice cv. Nerica 1 in aus season. Intl J Agron Plant Prod 2013;4(1):69-75.

26. Mahmud AJ, Shamsuddoha ATM, Haque MN. Effect of organic and inorganic fertilizer on the growth and yield of rice (Oryza sativa L.). Nature Sci 2016;14(2):45-54. doi:10.7537/marsnsj14021607.

27. Moe K, Htwe AZ, Thu TTP, Kajihara Y, Yamakawa T. Effects on NPK status, growth, dry matter and yield of rice (Oryza sativa) by organic fertilizers applied in field condition. Agric 2019;9:1-5. doi:10.3390/ agriculture9050109

28. Islam A, Chandrabiswas J, Sirajul Karim AJ, Salmapervin MST, Abu Saleque MD. Effects of potassium fertilization on growth and yield of wetland rice in grey terrace soils of Bangladesh. Res Crop Ecophysiol 2015; 10:64-82.

29. Sharma GK, Mishra VN, Maruti Sankar GR, Patil SK, Srivastava LK, Thakur SD, et al. Soil-test-based optimum fertilizer doses for attaining yield targets of rice under midland alfisols of Eastern India. Commun Soil Sci Plant Anal 2015;46:2177-90. doi:10.1080/00103624.2015.10 69319

30. Rajput PS, Srivastava S, Sharma BL, Sachidanand B, Dey P, Aher $\mathrm{SB}$, et al. Effect of soil-test based long-term fertilization on soil health and performance of rice crop in vertisols of Central India. Int J Agric Environ Biotech 2016;9(5):801-6. doi:10.5958/2230732X.2016.00102.9

31. PSA. Selected statistics on agriculture [Internet]. PSA, Quezon, Philippines, 2018. Available via https://psa.gov.ph/sites/default/files/ Selected\%20Statistics\%20on\%20Agriculture\%202018.pdf (Accessed 5 April 2020)

How to cite this article:

Troza M, Sutacio A, Polinar A, Rollon RJC. Soil nutrient status and yield of rice under organic and inorganic inputs. $\mathrm{J}$ Appl Biol Biotech 2021; 9(06):181-188. 